\title{
Charting Academic Freedom in Europe
}

\author{
Liviu Matei
}

\section{Introduction}

The paper discusses the need to chart a course for academic freedom in the European Higher Education Area (EHEA). It puts forward the following arguments:

- Presently, there is a crisis of academic freedom in the EHEA.

- This crisis is specific to Europe/EHEA ${ }^{1}$; it is not a global or national crisis, although there are challenges to academic freedom in all other parts of the world and also within individual national higher education systems in Europe.

- The crisis has two main dimensions: intellectual (conceptual) and empiric (political, regulatory, institutional).

- Efforts have been started recently and are underway to address key challenges to academic freedom in the EHEA and, moreover, to eventually plot a course out of this crisis.

- A comparative and applied interdisciplinary study of these efforts, outlined in the paper, helps reveal their nature and scope and identify the actors/stakeholders

\footnotetext{
${ }^{1} \mathrm{~A}$ brief summary of terminology in the context of research on European-wide issues in higher education, such as the distinction between EHEA and Bologna Process, is proposed by Matei and Iwinska: "The Bologna Process, launched with the Bologna Declaration of 1999, is a voluntary intergovernmental process in higher education based on jointly agreed principles, objectives and standards. Currently, there are 48 European states implementing the Bologna Process, which constitute the European Higher Education Area (EHEA). The EHEA, as the common European space for higher education, is considered a result of the Bologna Process. A European Research Area (ERA), which emerged at about the same time with the EHEA, developed as a major initiative under the Lisbon Agenda, the EU's overarching strategy between 2000 and 2010. ERA is defined as a 'unified research area open to the world based on the Internal Market, in which researchers, scientific knowledge and technology circulate freely and through which the Union and its Member States strengthen their scientific and technological bases, their competitiveness and their capacity to collectively address grand challenges' (Lisbon Treaty amending the Treaty on European Union and the Treaty establishing the European Community, signed at Lisbon, 13 December 2007)". (Matei and Iwinska 2018: 346).
}

L. Matei $(\bowtie)$

Central European University, Budapest, Hungary

e-mail: mateil@ceu.edu

(C) The Author(s) 2020

A. Curaj et al. (eds.), European Higher Education Area: Challenges for a New Decade, https://doi.org/10.1007/978-3-030-56316-5_28 
involved as well as those, astoundingly, absent. It also allows to discuss and assess early on the chances of success and identify challenges and gaps (some remarkably surprising) in these efforts.

\section{The Crisis of Academic Freedom in Europe}

There is a shared sense among higher education researchers and practitioners that the last ten years, and the last four-five in particular, have brought about significant challenges to academic freedom in Europe. Most often, discussions about these challenges take place in the broader framework of concerns about values, or fundamental values, in the EHEA (Steinel 2019; Noorda et al. 2020). In this context, the argument is made repeatedly that we should focus not only on structural (or technical) reforms within the EHEA but pay attention to a set of explicitly defined fundamental values in European higher education as well (Bergan and Matei, in this volume). A case can be made that a more accurate analysis of the situation compels us not only to talk about challenges here and there but unfortunately to acknowledge the reality of a genuine crisis of academic freedom in the EHEA (Matei forthcoming; Matei 2020).

Bologna Process was launched in 1999 with the objective to promote structural reforms while building a European-wide common space for dialogue and practice in higher education to support these reforms. For a relatively long period in Europe, in the years before and immediately after the launch of this continental-scale initiative in higher education, academic freedom was neglected, largely because it was taken for granted as an immutable value assumed to be understood and followed by all. And indeed, in the immediate post-communist, post-cold war era, this was largely the case - there was a broad consensus about the importance of academic freedom-only for the situation to start deteriorating markedly after 2008-2010. Particularly striking developments have contributed to the sudden realization that academic freedom is not doing well in the EHEA. Such was the case with the repressive measures against entire universities and scores of students and academics imposed by the Turkish authorities in the wake of the alleged coup d'état of 2016. Another case was that of the attacks against higher education and research launched by the Hungarian government since 2017, which forced Central European University (CEU) out of this country and resulted in disbanding the research network of the prestigious Hungarian Academy of Sciences. In reality, as analysed in detail elsewhere (Matei forthcoming), Turkey and Hungary are not the only countries in the EHEA showing disturbing signs of neglect of academic freedom, direct challenges to academic freedom and even its repression. Other countries exhibited worrying signals coming not only from the political, legal and regulatory realms impacting higher education but also from within higher education activities proper.

There are additional arguments and evidence for the assertion regarding a crisis of academic freedom in the EHEA. Together with Julia Iwinska, we have argued that a specific concept and regulatory model for institutional autonomy, understood in the sense of a set of freedoms for higher education institutions as institutions, have 
been developed in the EHEA — but nothing similar has been done for the notion of academic freedom, understood to refer also to specific freedoms of the individuals working in higher education institutions (Matei and Iwinska 2018). The findings of that piece of research have helped reveal, more importantly, that the EHEA is simply lacking a common conceptual reference for academic freedom. The EHEA has made possible the emergence of many new common concepts, models and tools in higher education, implemented with varying degrees of success across all or most of the 48 member countries, such as the EHEA standards and guidelines for quality assurance, ${ }^{2}$ the European Credit Transfer and Accumulation System $\left(\right.$ ECTS $\left.^{3}\right)$, the new Bologna degree structure and the new European models of master and doctoral education (Matei et al. 2018). The development by the European University Association (EUA) of a highly impactful model of institutional autonomy, consequential within but also outside the EHEA itself, is another example in this series. The "autonomy project" of the EUA was formally meant only to produce a tool for monitoring autonomy, not a conceptual model of autonomy (Estermann and Nokkala 2009; Estermann et al. 2011; Pruvot and Estermann 2017). We argue, however, that is has achieved exactly that (Matei and Iwinska 2018), contributing in this way significantly to asserting and promoting university autonomy, or a particular view on it, in the EHEA and beyond. The neglect of academic freedom, on the other hand, the fact that it was taken for granted and benefitted from no particular attention in the intellectual and policy reflection in the EHEA, resulted in the absence of a similar model or conceptual reference for it. A striking illustration of the consequences of the lack of a European, or common-European, reference for academic freedom emerged when the European Commission took Hungary to court for infringement of academic freedom in the case of CEU. The Hungarian government retorted asking "based on what?" and stated that the EU courts had no jurisdiction since there is no such thing as a European definition, let alone legal principle about academic freedom (Matei forthcoming). The Commission was almost willing to oblige and considered, at least for a certain period of time, reclassifying the CEU case into one about the right to deliver commercial services only (for which European legislation exists), not academic freedom. ${ }^{4}$

Other researchers have documented for the case of the United Kingdom that not only policy-makers and regulators but also many, if not most, individual academics have no clear understanding or representation about what academic freedom means in Europe these days (Karran and Mallinson 2017).

\footnotetext{
${ }^{2}$ https://enqa.eu/index.php/home/esg/, accessed on 20 March 2020.

${ }^{3}$ https://ec.europa.eu/education/resources-and-tools/european-credit-transfer-and-accumulationsystem-ects_en, accessed on 20 March 2020.

${ }^{4} \mathrm{~A}$ verdict in this case before the European Court of Justice (ECJ) is expected by September 2020, three years after the adoption of the legislation in Hungary that obliged CEU to leave the country. In March 2020 the ECJ Advocate General issued a formal opinion for the Court asserting that the Hungarian higher education law does infringe academic freedom and the European legislation on academic freedom (https://www.courthousenews.com/wp-content/uploads/2020/03/ecjhungary.pdf accessed on 6 March 2020). If this opinion were accepted by the ECJ and transformed into a verdict, it would create a major legal precedent and a milestone for the definition and protection of academic freedom in the European Union.
} 
These and related findings support the argument about a crisis of academic freedom in the EHEA. This crisis—it should be stressed again- has two main dimensions.

The intellectual dimension has not been studied systematically to date. It is reflected in neglect and underdevelopment of academic freedom as a concept and in this absence of a (common) conceptual reference for academic freedom for the entire EHEA. The Bologna Process and the EHEA have supported, even generated, a large and multifarious process of intellectual and professional reflection and elaboration that resulted in new or refined concepts in higher education, as summarized above. Again, no such efforts have focused on academic freedom. In spite of occasional generic statements about the importance of academic freedom, such as the Magna Charta Universitatum (1988), this concept remained underdeveloped altogether and absent as a common European reference after the launch of the Bologna Process in 1999. As already put forward in other publications (Matei forthcoming, 2019, 2020), the situation of academic freedom in the EHEA can be compared metaphorically to that of an imposing physical edifice, a large and complex compound with many halls, windows and corridors-some beautiful, some not quite so, some finished and functional, some not yet or not at all — but for which, in any case, the architect has forgotten to design a ventilation system. Without it, everybody in the compound suffers the risk of suffocation, from only mild to severe and deadly. Without academic freedom, the EHEA cannot work properly either; it runs the risk of suffocation.

Seen in this light, the crisis of academic freedom in the EHEA appears as a specific one, not just as a manifestation of challenges or even a crisis of a global nature, discussed in reputable publications (see, for example, the volume edited by M. Ignatieff and S. Roth titled exactly that: Academic freedom-the global challenge, Ignatieff and Roch 2017). The EHEA can be understood as the result of a formally elaborated project, the Bologna Process. EHEA and, with it, many of the evolutions in higher education in Europe after 1999-2000, did not just happen. The common space for dialogue and practice in higher education in Europe was built with a program, based on a relatively detailed blueprint evolving over a little more than 20 years now. Only that the conceptual underpinning of this "program" missed an important element: academic freedom, because it has been taken for granted at that time. The blueprint for the construction of the EHEA lacked any sections on academic freedom and did not make possible any "execution drawings" for it. That has led to a skewed construction-and a crisis.

This is not a crisis of academic freedom in the particular states of Europe either. In some of them, in spite of clear and present dangers and challenges, academic freedom is well respected and protected, including through adequate national legislation. Many European countries have strong, well elaborated and effective legal instruments for the protection of academic freedom (Beiter et al. 2016). However, in the EHEA, in this integrated common space, that is not sufficient: one country depends on the others, and higher education activities are affected overall even if academic freedom is restricted in some although not all countries. To take just one example: Norway (a member of the EHEA) has some of the best articulated and most efficient legal provisions and mechanisms to protect academic freedom. However, when a 
Norwegian student goes with one of the many Erasmus exchanges to Hungary, that person will not have the freedom to enrol in a gender studies program and cannot study (or teach, for academics) gender studies because this discipline or academic area has been banned in Hungary through a government decree since 2018 (Redden 2018). In the EHEA, academic freedom is not or not only a national matter. The crisis of academic freedom is specific to this entire European initiative or space, which is the EHEA. It is not a sum of national crises; it is a European or EHEA crisis. As such, it might require a European, rather than a national or global solution. Like the EHEA itself, a concept or model of academic freedom for this area cannot just happen, it will not emerge spontaneously. A course for academic freedom needs to be plotted programmatically.

The second and related dimension of the crisis is empiric, as discussed above in this paper, be it only cursorily: academic freedom is challenged and threatened "on the ground" in all parts of the EHEA, although to different degrees; it is even severely repressed in some member countries. We have reviewed extensively elsewhere the evidence for this statement (Matei 2019, 2020, forthcoming).

What are the origins of this crisis? This is a relatively recent episode in the EHEA. It is also a somewhat surprising, unexpected one. Although not explicitly conceptualized and operationally promoted, academic freedom was largely accepted by all major stakeholders as a value and guiding principle in the first years of the Bologna Process. The favourable European context at that time (the first decade of the millennium) mattered, in particular, given a set of supportive powerful policy narratives such as Europeanization, democratization, or knowledge society and their corresponding epistemologies relevant for the social contract with regard to higher education. There was large public and political support for higher education in Europe, including for academic freedom. This situation started to change in the years after the great recession of 2007-2009, with the corrosion of these powerful public policy narratives and their progressive and at least partial replacement by alternative narratives and social epistemologies, such as those influenced by populism and neo-nationalism (Matei and Iwinska 2018; Slaughter 2019). These new narratives, in turn, have not been appreciative and supportive of advanced knowledge production and higher education more generally and could not easily tolerate, let alone promote, democratic freedoms altogether, including academic freedom in particular.

We need to note that the studies of academic freedom in the EHEA, which remain limited in number anyway, have almost always concentrated on macro-aspects, such as on national regulations and the actions of state authorities, and only extremely rarely on internal institutional practices and activities. Moreover, while national legislation, including constitutional provisions for academic freedom, exist in most European countries, individual universities themselves rarely have any institutional provisions, definitions, strategies or policies about academic freedom. These are two other expressions of the conceptual underdevelopment of academic freedom in Europe. 


\section{Overcoming the Crisis: Charting Academic Freedom in Europe}

If we accept that a crisis of academic freedom in the EHEA with characteristics and origins as discussed above is a reality, what is the way out? Are there any forces at work to overcome the crisis? Who are they? Who should they be? What do this work or these efforts entail anyway, and what should they entail? The EHEA is indeed suigeneris but is there anything we can learn from the research literature on academic freedom in the history of higher education in Europe itself or from non-European experiences, past and present, which could be useful for these efforts?

Europe has a convoluted but often inspirational history of academic freedom. Other parts of the world have their own history with academic freedom as well, with high points and with nadirs, sometimes going back in time at least decades if not centuries, full of potentially useful lessons for understanding and addressing today's challenges. This is true even when these traditions, contemporary challenges and experiences are not extensively studied or just not well-known even among specialized scholars in the "Global North" (of which the EHEA is clearly a part), as is often the case with Latin America, the Middle East, Africa or most parts of Asia.

It can be stated that the scholarship of academic freedom focusing on the twentieth and beginning of the twenty-first centuries is more developed in the US than anywhere else, including Europe. So are the intellectual reflection about academic freedom and the quantity of work, even "militantism" in its favour among higher education leaders and higher education "intermediate organizations" (Slaughter 2019) that help structure the governance field of higher education, including academic freedom.

An analytical framework for the study of academic freedom, including in times of crisis like the current one in the EHEA, could be developed based on the existing scholarship and taking into account experiences from all parts of the world. It could help answer the questions listed at the beginning of this section. It would also, most likely, help address these matters in practice, beyond research and scholarship alone. Unfortunately, no such analytical framework is available, let alone one that would be suitable for the current times and realities, which could be put at work in this EHEA crisis case. The present paper does not attempt to build and utilize one either. Instead, it attempts a focused, limited and less ambitious historic and comparative exercise to help shed light not on the recent crisis of academic freedom in the EHEA as a whole, but rather on the current efforts to address it, looking at actors involved/absent, scope and likely impact.

The succinct analysis developed in the first section of the paper suggests by way of logical implication that what is needed in Europe/the EHEA is the development of a novel concept of academic freedom, one that would be adapted to the reality of this sui generis and unprecedented transnational, continental-wide common space for higher education. Existing national solutions (such as national legislation) are not sufficient. A global or broader international solution is not at hand, in spite of the dedicated work and efforts in this area, usually linked with concerns for human rights protection, of a few international organisations, such as the UN, UNESCO, 
the Council of Europe or even the European Union (Matei and Iwinska 2018). An EHEA solution is both necessary and possible. The work to develop it requires what we could call "charting academic freedom in Europe". The reference to charting is borrowed and adapted here from a recent publication in the US (Randall 2018). This is a remarkable volume taking the form of a simple collection of texts (statements and reports) about academic freedom from the US, also comprising a simple timeline (not extensively commented) of the most important court cases about academic freedom during the last hundred years. Both the texts and list of court cases represent, in fact, the main milestones in the definition, defence and framing of the practice of academic freedom during this period in the US. Indeed, a remarkable publication, powerful in its simplicity. It is also a very good comparative reference for us in Europe.

For the case of the EHEA, I propose to understand "charting" in two ways: as delineating the meaning or understanding for a new concept of academic freedom (similar to an explorer charting a new territory) and as plotting a course for academic freedom (similar to how a ship captain or a pilot is physically, concretely plotting the course for their vessels across the sea or in the sky above the land). Such charting efforts are already underway in the EHEA, and they pursue both paths: defining a new conceptual understanding of academic freedom for the entire EHEA and projecting/plotting a conduit for moving beyond its current crisis.

In 2018 (which is very recently indeed), ministers responsible for higher education from the EHEA countries met in Paris for one of their periodic Ministerial Conferences, along with representatives of the EU Commission, European and international inter-governmental and non-governmental organizations, and a small number of university observers. The Ministerial Conference ${ }^{5}$ is the main decision-making and governing structure of the EHEA. The direction of the process and all other key decisions have been taken in this forum since the very start of the Bologna Process, in the form of voluntary commitments that member countries agree to implement at home. In Paris, following pressure and discreet (read "anonymous") advocacy by influential and shrewd stakeholders - mainly individuals with European institutional backing but some others as well — the Ministers included a clear statement about academic freedom and other fundamental values that at least recognizes the importance of academic freedom and the fact that it is not doing too well in EHEA, if not the reality of a crisis:

Academic freedom and integrity, institutional autonomy, participation of students and staff in higher education governance, and public responsibility for and of higher education form the backbone of the EHEA. Having seen these fundamental values challenged in recent years in some of our countries, we strongly commit to promoting and protecting them in the entire EHEA through intensified political dialogue and cooperation. (Bologna 2018)

After the Conference, a "Task Force for future monitoring of values" " was established by and under the auspices of the Bologna Follow Up Group $\left(\mathrm{BFUG}^{7}\right.$ - the body

\footnotetext{
${ }^{5}$ http://www.ehea.info/page-ministerial-declarations-and-communiques, accessed March 6, 2020. ${ }^{6}$ http://www.ehea.info/Upload/Board_HR_UA_68_4_5_WG1_Task_Force.pdf, accessed March 6, 2020.

${ }^{7} \mathrm{http}: / /$ ehea.info/page-the-bologna-follow-up-group, accessed March 6, 2020.
} 
entrusted to oversee the Bologna Process between the Ministerial Conferences) to design and propose: a European/EHEA definition of academic freedom, a statement on academic freedom and, eventually, indicators and a mechanism or process for monitoring academic freedom. (The author of the present paper interacted with the Task Force as an invited, non-member expert.) It is expected that the task force will submit proposals on the three items by the next Ministerial Conference, which will take place in Rome in fall 2020. While it is not certain that the task force will complete its work by the time of this meeting (it might even ask itself for more time), there is a good chance that this it will, and three historic proposals on academic freedom will be on the tables of the ministers. It is also not certain that the BFUG will approve and agree in the end to submit any proposals at all to the ministers, and then also not certain the ministers will approve them. If adopted, it is not certain how or if they will ever be put in practice. It is possible for only the explorer part of the charting metaphor to materialize (a new territory will be charted-a definition will be adopted), but the ship captain or aircraft pilot part of it will not (the ship will never leave the shore, the plotted course will not be followed). Still, there is now a high likelihood that this process will be completed, ${ }^{8}$ and by summer 2020 or not long after that (a couple more years?), we may have a European definition, or what is called in this paper a "common conceptual reference", for academic freedom and projections for a mechanism to protect and promote academic freedom throughout the EHEA.

These are clearly efforts aiming at charting academic freedom on both dimensions proposed here. They represent a fundamentally genuine, positive, well-intended and daring endeavour. There is little knowledge about these efforts within the academic community in Europe (a matter of lack of transparency, or tactics?) but it should support them because they are meant to serve primarily exactly this community. And yet, it is possible already to see major shortcomings and risks. A comparison of these European charting efforts with those in the US reveals striking differences and also astounding characteristics of the European endeavour. In the US, the main actors involved were university associations (such as the American Association of University Professors-AAUP and the Association of American Colleges and Universities-AACU), courts, but also individual universities and even individual academics as academics, as well as student voices. The volume referred to above (Randall 2018) includes moments and texts such as the adoption of the well-known principles on academic freedom and tenure first developed by AAUP in 1915 and endorsed later by AAUC, but also milestones named after individuals who led singleuniversity committees that developed reports or statements on academic freedom. The Kalven report of 1967 (Report on the University's Role in Political and Social Action) is one of the best known but not the only one. The more recent (2017) Statement of Purpose: Free Expression on Campuses was developed by a body called Students for Free Expression. These documents emanating from universities, aca-

\footnotetext{
${ }^{8}$ The Task Force proposal for a definition of academic freedom was already approved by the BFUG on March 4-5, 2020, at its meeting in Kyiv.
} 
demics and students — and not from public authorities - have indeed played a role in charting academic freedom in the US.

The current EHEA charting efforts are conducted almost exclusively by representatives of ministries/governments and intergovernmental organizations (the EU and the Council of Europe) who are members of the BFUG. The European University Association and a European federation of teachers' trade unions (ETUCE/Education International) are also providing input along with a handful of independent experts. Fundamentally, this is an intergovernmental endeavour, like the Bologna Process itself. There is no input, let alone leadership in the charting of academic freedom in the EHEA coming from higher education institutions, academic leaders or students. The scope of these efforts is limited, as circumscribed by the limits of the Bologna Process as an intergovernmental voluntary process using "soft law governance" (Deca and Harmsen in this volume). The nature of this process of charting academic freedom is largely intergovernmental, meaning also bureaucratic, before being even political, although it benefits from significant energy, commitment and expertise from devoted and knowledgeable individuals working in these governmental or inter-governmental (bureaucratic) structures. Universities, academics and students are missing. The result will bear the marks of this configuration of actors involved - and absent. Having a common European reference for academic freedom will be a major, good and necessary development. Excluding universities, academics and students from the process of developing it, however, will limit, among others, its legitimacy and the degree of acceptance in the academic world, will run the risk of being too overly political and bureaucratic, thus limiting its capacity to facilitate the work of universities, university staff and students, which academic freedom is for. Taking a first big step is good. Corrections can be made later. Will that, however, risk being too late?

\section{References}

Beiter, K. D., Karran, T., \& Appiagyei-Atua, K. (2016). Academic Freedom and Its Protection in the Law of European States Measuring an International Human Right. European Journal of Comparative Law and Governance3, 254-345.

Bologna Process. (2018). Paris Communiqué. Accessed at http://www.ehea.info/Upload/document/ ministerial_declarations/EHEAParis2018_Communique_final_952771.pdf on March 6, 2020

Estermann, T., \& Nokkala, T. (2009). University Autonomy in Europe I-Exploratory study. Brussels: European University Association.

Estermann, T., Nokkala, T., \& Steinel, M. (2011). University Autonomy in Europe II. The Scorecard. Brussels: European University Association.

Ignatieff, M., \& Roch, S. (Eds.) (2017). Academic freedom: the global challenge. CEU Press.

Karran, T., \& Mallinson, L. (2017). Academic Freedom in the U.K.: Legal and Normative Protection in a Comparative Context. Report for the University and College Union. Accessed at https://www.ucu.org.uk/media/8614/Academic-Freedom-in-the-UK-Legal-and-NormativeProtection-in-a-Comparative-Context-Report-for-UCU-Terence-Karran-and-Lucy-MallinsonMay-17/pdf/ucu_academicfreedomstudy_report_may17.pdf on March 6, 2020 
Matei, L. (2019). The Virtues of Cooperation, Complementar ity and Competition in Higher Education in Time of Crisis. In R. Pritchard et al (Eds.), The Three Cs of Higher Education: Competition, Collaboration and Complementarity. CEU Press

Matei, L. (2020). The crisis of academic freedom in Europe. In S. Noorda, P. Scott \& M. Vukasovic (Eds.), Bologna Process beyond 2020: Fundamental Values of the EHEA. Bononia Press

Matei, L. (forthcoming). Academic freedom, university autonomy and democracy's future in Europe. In S. Bergan, T. Gallagher \& I. Harkavy (Eds.), Academic Freedom, Institutional Autonomy, and the Future of Democracy (forthcoming; publication expected in May/June 2020).

Matei, L., \& Iwinska, J. (2018). Diverging Paths? Institutional Autonomy and Academic Freedom in the European Higher Education Area. In A. Curaj, L. Deca \& R. Pricopie (Eds.), European Higher Education Area: The Impact of Past and Future Policies.Cham: Springer.

Matei, L., Torotcoi, S., \& Craciun, D. (2018). A resounding success or downright failure? Understanding policy transfer within the Bologna Process in Central and Eastern Europe. In A. Batory, A. Cartwright, \& D. Stone (Eds.), Policy Experiments, Failures and Innovations: After Accession in Central and Eastern Europe. Edward Elgar Publishing

Noorda, S., Scott, P., \& Vukasovic, M. (Eds.) (2020). Bologna Process beyond 2020: Fundamental Values of the EHEA. Bononia University Press

Pruvot, E., \& Estermann, T. (2017). University Autonomy in Europe III. The Scorecard. Bruxelles: European University Association.

Randall, D. (2018). Charting Academic Freedom. 103 Years of Debate. National Association of Scholars, New York

Redden, E. (2018). Hungary Officially Ends Gender Studies Programs. Inside Higher Ed. October 17, 2018. Accessed at https://www.insidehighered.com/quicktakes/2018/10/17/hungaryofficially-ends-gender-studies-programs on March 6, 2020.

Slaughter, Sh. (2019). Challenges to Academic Freedom: Academic Capitalism and Neonationalism. In R. Pritchard et al (Eds.), The Three Cs of Higher Education: Competition, Collaboration and Complementarity. CEU Press

Steinel, M. (2019). The value of values for Europe's universities. Accessed at https://eua.eu/ resources/expert-voices/124-the-value-of-values-for-europe $\% \mathrm{E} 2 \% 80 \% 99$ s-universities.html on March 6, 2020.

Open Access This chapter is licensed under the terms of the Creative Commons Attribution 4.0 International License (http://creativecommons.org/licenses/by/4.0/), which permits use, sharing, adaptation, distribution and reproduction in any medium or format, as long as you give appropriate credit to the original author(s) and the source, provide a link to the Creative Commons license and indicate if changes were made.

The images or other third party material in this chapter are included in the chapter's Creative Commons license, unless indicated otherwise in a credit line to the material. If material is not included in the chapter's Creative Commons license and your intended use is not permitted by statutory regulation or exceeds the permitted use, you will need to obtain permission directly from the copyright holder.

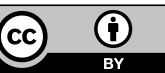

